\title{
CONTEMPORARY PRINCIPLES OF URBAN DESIGN OF METROPOLIS. SCALE OF PLANNED DEVELOPMENT UNITS AND DIVERSITY
}

\author{
WSPÓŁCZESNE ZASADY PROJEKTOWANIA URBANISTYCZNEGO \\ METROPOLII. SKALA PLANOWANYCH JEDNOSTEK I RÓŻNORODNOŚĆ
}

\section{Krystyna Guranowska- Gruszecka}

prof. dr hab. inż. arch.

Author's Orcid number: 0000-0003-2901-8936

Akademia Finansów i Biznesu Vistula, Warszawa

Europejski Wydział Sztuk

\begin{abstract}
The aim of the article is to draw readers' attention to radical changes that occur in the contemporary life of the developing civilization, which entails the necessity to adapt to these changes. Accommodating to these changes is not always successful, whereas in Poland the process usually takes place with a delay of about 50 years, compared to Western Europe. In the field of architecture and urban planning, it is necessary to pay attention to the distribution of places of residence in relation to the location of workplaces and leisure facilities in rapidly growing metropolises.
\end{abstract}

Key words: functional and spatial transformations, metropolises, new design principles, urban transport, diversity.

\section{STRESZCZENIE}

Przedmiotem artykułu jest zwrócenie uwagi czytelników na diametralne zmiany, jakie następują w naszym współczesnym życiu rozwijającej się cywilizacji, co pociąga za sobą konieczność dostosowania się do nich, a nie zawsze to następuje, w Polsce zwykle z opóźnieniem o około 50 lat w stosunku do Europy Zachodniej. W dziedzinie architektury i urbanistyki dotyczy to przede wszystkim rozmieszczenia miejsc zamieszkania w stosunku do lokalizacji miejsc pracy i odpoczynku w rozrastających się gwałtownie metropoliach.

Słowa kluczowe: przekształcenia funkcjonalno-przestrzenne, metropolie, nowe zasady projektowania, transport miejski, różnorodność. 


\section{INTRODUCTION}

The present article is intended to explain the reasons why for many people workplaces are located so far away from their dwellings. A question arises if the situation can be avoided. Urban-planning solutions applied in other Western European cities will provide an answer to this question. The article presents the location of service, office and industrial districts in the city, that is the functional-spatial shaping of urban structures. Moreover, elements of the urban network are presented. The design of these elements and the results of these processes must now be conducted in a completely new way for the city to function efficiently and for its people to enjoy inhabitant-friendly solutions.

The method applied for reaching conclusions with which to determine the necessity to introduce changes in city design and transformations thereof is to compare the condition of the city as it is to other, better design plans. The comparison juxtaposes Warsaw conditions (mostly) to those observable in old European cities (especially in London - the world's leading metropolis in terms of urban planning principles applied). The comparison accounts for both, everyday functioning and the assessment of all the advantages and disadvantages of a given system.

In the conclusions sections knowledge is drawn from examples of positive solutions applied worldwide, as well as from the already established and recognized urban planning theories that have governed contemporary design guidelines in force in the West since the 1970s. However, these design principles are still underestimated in Poland.

\section{MODERNIST URBAN DESIGN AGAINST THE BACKGROUND OF CONTEMPORARY TRENDS}

Urban design in modernism consisted in designating specific areas for housing estates, service centres (hierarchical centers: city, district and local housing estates), industrial, or recreational-sports areas. Thus, mostly large clusters of residential building developments were constructed, where basic services, though incomplete, were introduced. Services found in such housing estates included those essential for the existence of every family, namely schools, kindergartens, nurseries, health centers, sometimes individual grocery stores. However, for bigger shopping, it was necessary to go to the center of the district or city. Similarly, workplaces were concentrated in separate districts. In favour of these layouts, a significant amount of greenery in housing complexes, a currently raised issue, (Wojtowicz W., 2019) should be emphasized.

Larger industrial districts were fitted only with production plants and warehouse facilities, there were no additional supporting functions. Similarly, recreational areas, e.g. parks or sports fields, were filled with greenery and sports fields, but lacked any additional attractions or services to facilitate spending time comfortably there.

Nowadays, all these spheres of our life: living, work and rest are supported by a variety of accompanying programme. This provides not only functional support, but it leads to enrichment of the spatial environment in which we live, so that our existence is attractive and balanced.

\section{RELATIVE CONCEPT OF ATTRACTIVENESS OF URBAN SPACE}

The relative concept of the attractiveness of urban space is reflected in the division of the society into generations $X, Y, Z$, already in common use. Young representatives of the $Z$ generation (on average ages from 19 to 26 ) are recipients of all the latest technologies, not always health-promoting ones. The generation is characterized by changing career ideas and varying leisure activities. These young people hold completely different views on how to live an interesting, pleasant and successful life. If it happens that Z-generation persons have already explored all the possibilities for enhancing their development at a particular workplace, they tend to change the workplace (Rykla Z., Kinala J., 2016). Therefore, personal development of an individual constitutes a positive aspect of work. Representatives of generation $\mathrm{Y}$, on the other hand, are generally difficult, because they tend to rebel and protest against everything. Generation X consist of older people born after the WW II. They are 
believed to be full of knowledge, experiences, well-dressed, full of principles that the younger generations fail to understand, as they do not cherish the same values (Rykla Z., ibidem).

In the view of acceleration of changes in place since 1950s and shifts that are still occurring at a rapid pace, the designed spatial environment must meet the needs and offer chances to fulfil ambitions and dreams of all social groups as participants in the life of the metropolis. As explained above, these desires may differ significantly. When deliberating with students and young architects on types of city models that would meet the needs of youth, opinions are expressed that the city should resemble a computer game. According to students, the city should be crazy, full of surprises, with surprising attractions. It should inspire both admiration and amazement, provoke unusual behaviours, create reality with the help of the latest inventions (implicitly technology or trends). This approach stands in opposition to the needs of older generations, who are satisfied if their city provides them with incentives to meet their needs and with entertainment, but in a more moderate manner.

These considerations point to the fact that in order to satisfy all age groups, cities need a variety of spaces (in open areas and indoors) managed in various ways, each time able to meet the lifestyle needs and to provide ways of spending time for these groups.

\section{CHARACTERISTICS OF FIRST IMPLEMENTATIONS OF NEW CENTERS IN DOWNTOWN WARSAW AFTER 1989}

Firstly, new implementations which grew rapidly after 1989, based on the principle of synergy, will be analysed. In many cities, and especially all over Warsaw, new complexes of building developments were introduced in post-industrial, post-railway and post-port areas. Along with the political breakthrough of 1989, industry of all kind was liquidated. Deindustrialization process took place both in Służewiec Przemysłowy (Industrial Służewiec) in Warsaw, in Wola, but also in the post-railway areas of the northern part of Downtown Warsaw. Moreover, areas along Al. Jerozolimskie - the main W-E route of the capital, previously free of buildings, was now developed. A two-sided housing development with large-area services and offices was introduced along this street, from the borders of Downtown Warsaw to the borders of the capital city of Warsaw (Fig. 2)

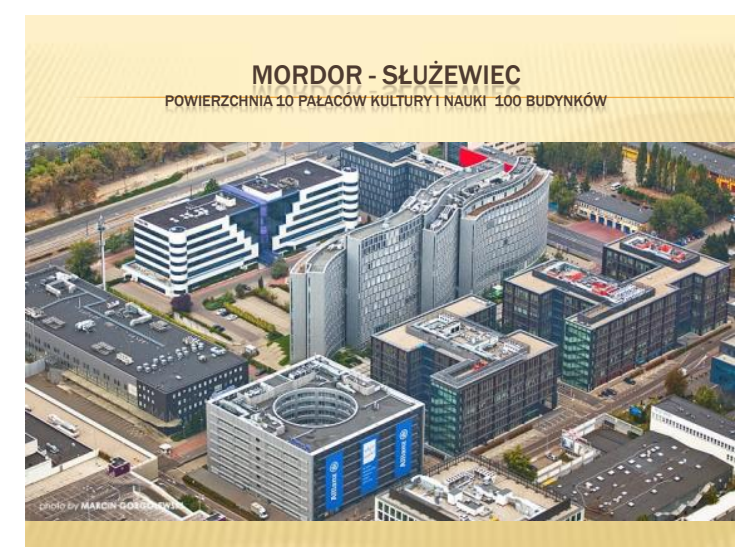

Fig. 1. "Mordor". Planned office complex that constitutes $1 / 10$ of the office complex (from the author's archive, 2017)

Ryc. 1. "Mordor". Planowany zespół biurowy stanowiący 1/10 zespołu biur ( $z$ archiwum autorki, 2017)

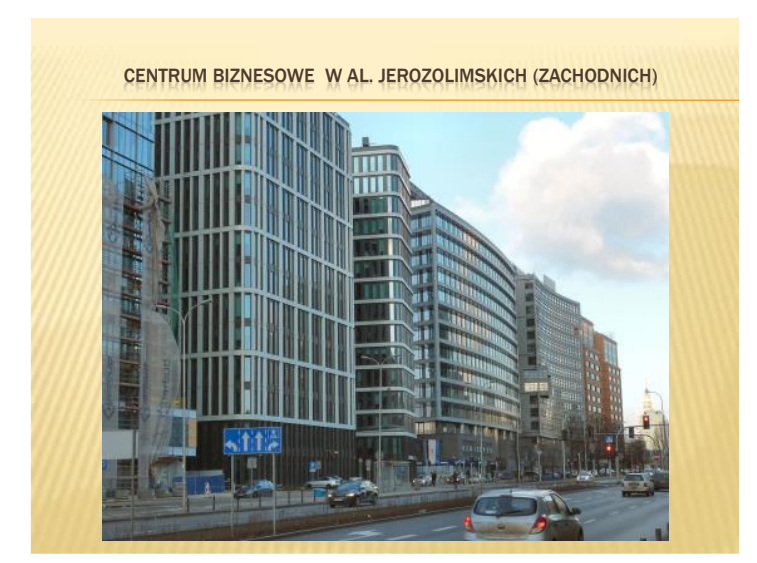

Fig. 2 A new office complex on the northern side of Al. Jerozolimskie - no generally available services on the ground floors (photo K. Gruszecka 2018)

Ryc. 2 Nowy zespół biur po północnej stronie Al. Jerozolimskich - brak ogólnie dostępnych usług w parterach (fot. K. Gruszecka 2018)

The closure of the port on the Vistula River in Praga Północ may be seen as yet another example of Warsaw entering the post-industrial era in the early 1990s (Gruszecka K. Kordek M.). Interestingly, 
similar processes took place in other European capitals. In London, for example, industrial development was liquidated in the centre next to the so-called London Docks in 1980s. This process resulted from the fact that places were needed to stop and reload much larger ships that carried minerals mined in other countries of the world. The depth of the Thames did not allow such large and heavy loads to pass. The port was thus moved closer to the estuary. ${ }^{1}$ The former docks are now wellfunctioning enclaves of multifunctional service and complexes of housing estates. These changes, however, were not easy, and required changes in urban planning and implementation guidelines ${ }^{2}$.

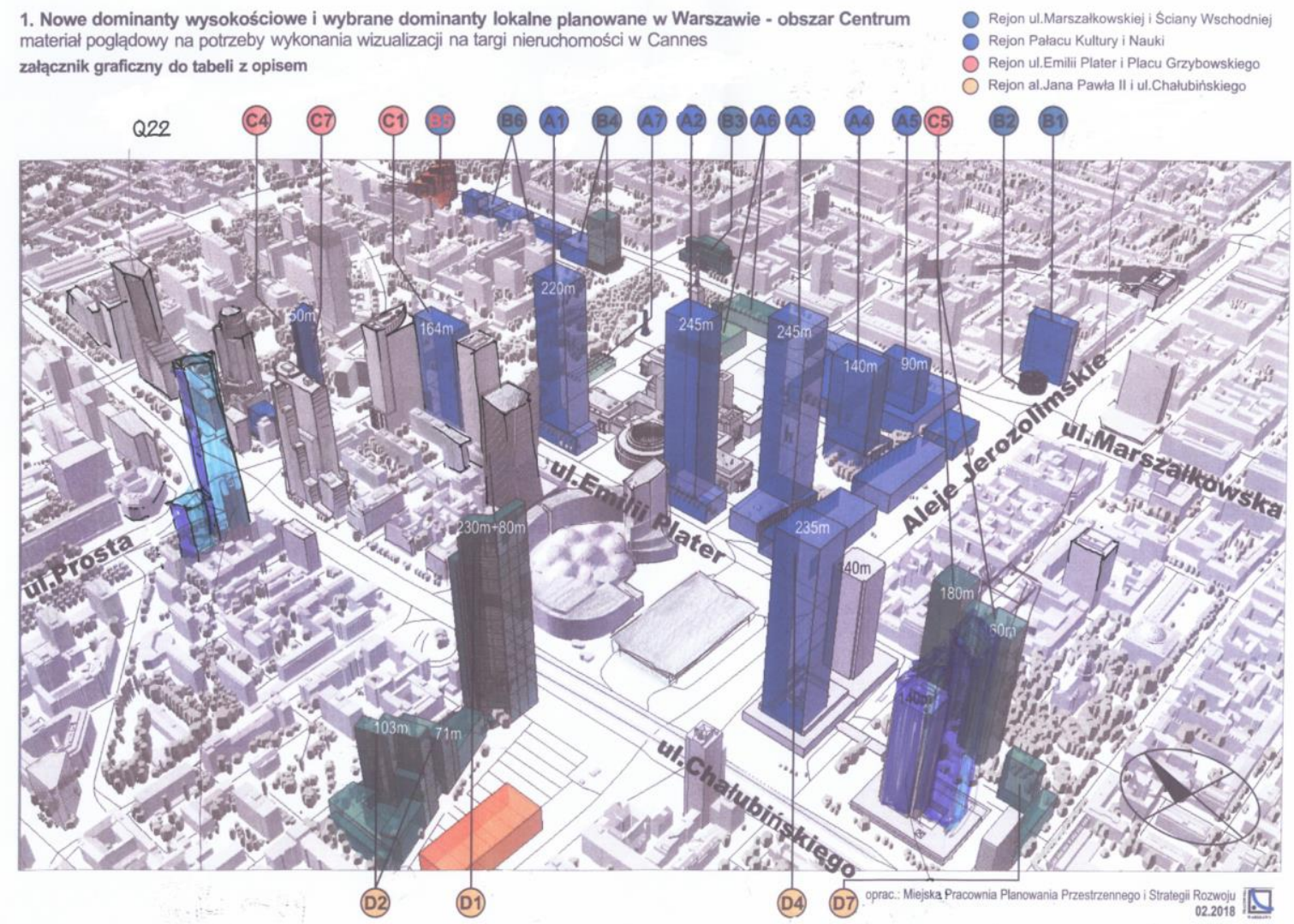

Fig. 3 Visualization of the Centre of Western Warsaw with the existing and planned high-rise buildings (prepared by Wojciech Oleński, 2018). Materials presented at one of the world's largest real estate fairs in Cannes.

Ryc. 3 Wizualizacja Centrum Zachodniego Warszawy z istniejącą i planowaną zabudową wysoką (oprac. Wojciech Oleński, 2018). Materiały prezentowane na jednych $z$ największych na świecie targach nieruchomości w Cannes

\footnotetext{
${ }^{1}$ In the doctoral dissertation, MSc. Arch. Jolanta Cory: The genesis of the spatial structure of the London Docklands, the author presents the entire process of liquidation of the production and warehouse development in London docks from the times of British Empire that ruled in numerous colonies and which imported minerals extracted in distant overseas countries to London ports, including e.g. coal, iron ore, wool, cotton, wheat, etc.; Library of the Faculty of Architecture, Warsaw University of Technology 2019.

${ }^{2}$ The structures and principles of operation of Urban Development Corporations will be described in the second part of the article, including those concerning the management and comparison of these methods in Poland with Great Britain in terms of the effectiveness of activities.
} 
In Warsaw, on the other hand, mono-functional office complexes were built along ul. Jana Pawła II (Jana Pawła II Street) relatively quickly after 1989. So were the lines of office blocks devoid of services on the ground floors along the northern frontage of Al. Jerozolimskie. On the southern side of the street, large-area retail service facilities were implemented along the stretch of several kilometres. The modernist principles for designing large complexes of buildings with homogeneous functions and with similar spatial arrangements of buildings were carefully applied (Fig. 1). A peculiar example of such an approach is located in the area of the former Służewiec Przemysłowy. Known today as Mordor, the area is entirely covered with office buildings. The office blocks in the area are sometimes demolished after 10 years of their existence, in order to build some multi-family housing estates there.

In turn, the area of the Port Praski, should, at least to some extent, provide a generally accessible area for services and entertainment for residents and tourists, as it features a view of the opposite bank of the Vistula River and the historical panorama of the city. However, the investor has been stubbornly aiming at implementation of multi-story apartment buildings, with which to occupy the piers of the former port. The question arises, however, whether this fragment of the city, with its unique landscape, should rather be made available to the inhabitants and users of these areas. The more so as the area adjoins a protected zone of Natura 2000, with greenery along the Vistula (Guranowska-Gruszecka K., Kordek M.) (Fig. 4).

\section{PORT PRASKI - DYSKKUSJA CZY MA TO BYĆ OSIERLE ZAMKNIETE CZY OGÓLNIE ROSTEPNE?}

\section{TAK SIĘ ZMIENIA PORT PRASKI}

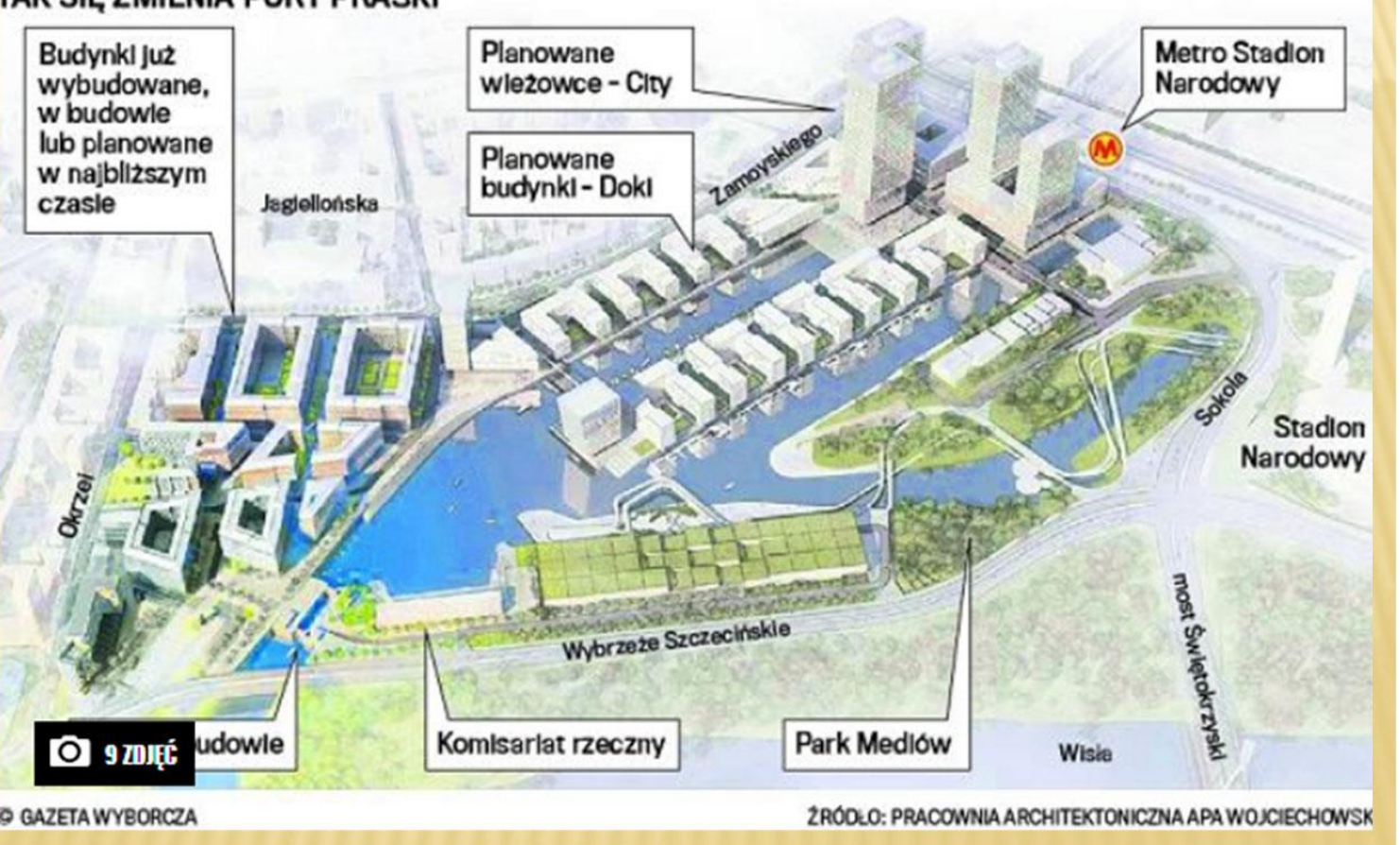

Fig. 4 Port Praski in Warsaw. Piers to the port intended for multi-family housing; at the back of this building complex, in the area of the railway embankment, there is a underground station and high-rise buildings (Gruszecka/Kordek, Port Praski...) Ryc. 4 Port Praski w Warszawie. Pirsy po portowe przeznaczone na zabudowę mieszkaniową wielorodzinną; na tyłach tego zespołu zabudowy w rejonie nasypu kolejowego przystanek metro oraz zabudowa wysoka (Gruszecka/Kordek, Port Praski...) 
Nowadays, these mono-functional building complexes have been in operation for 15-25 on average. Sometimes, they give the impression of a lunar landscape, with no people, traffic or life, even though the area is in the city centre, while the architecture of its buildings is impressive, contemporary, minimalist and very elegant. Residents and users of these areas, as well as architects and urban planners in particular, reckon that it was a mistake to introduce such mono-functional arrangements across large areas in the centre of the metropolis or in its outskirts. It happens that 4-storey residential buildings, implemented 10 years earlier, as the design that won the first prize in an architectural competition, are now demolished. This is done in order to build high-rise residential buildings, i.e. to obtain more square meters of space for sale. Such cases spark an outrage among urban planners.

It has already been discovered that office building complexes also need to be supplied with adjacent or neighbouring recreational areas with benches, attractive greenery and with water elements (small reservoirs, fountains, etc.). The climatic conditions of our times and the rules of work, even in corporations, require short breaks for eating or resting in good, aesthetic and health-friendly conditions. It is also advantageous to provide such development units with open air or roofed shopping arcades. It is known today that such a supplementation of office buildings is necessary in order to create better conditions for performing office tasks.
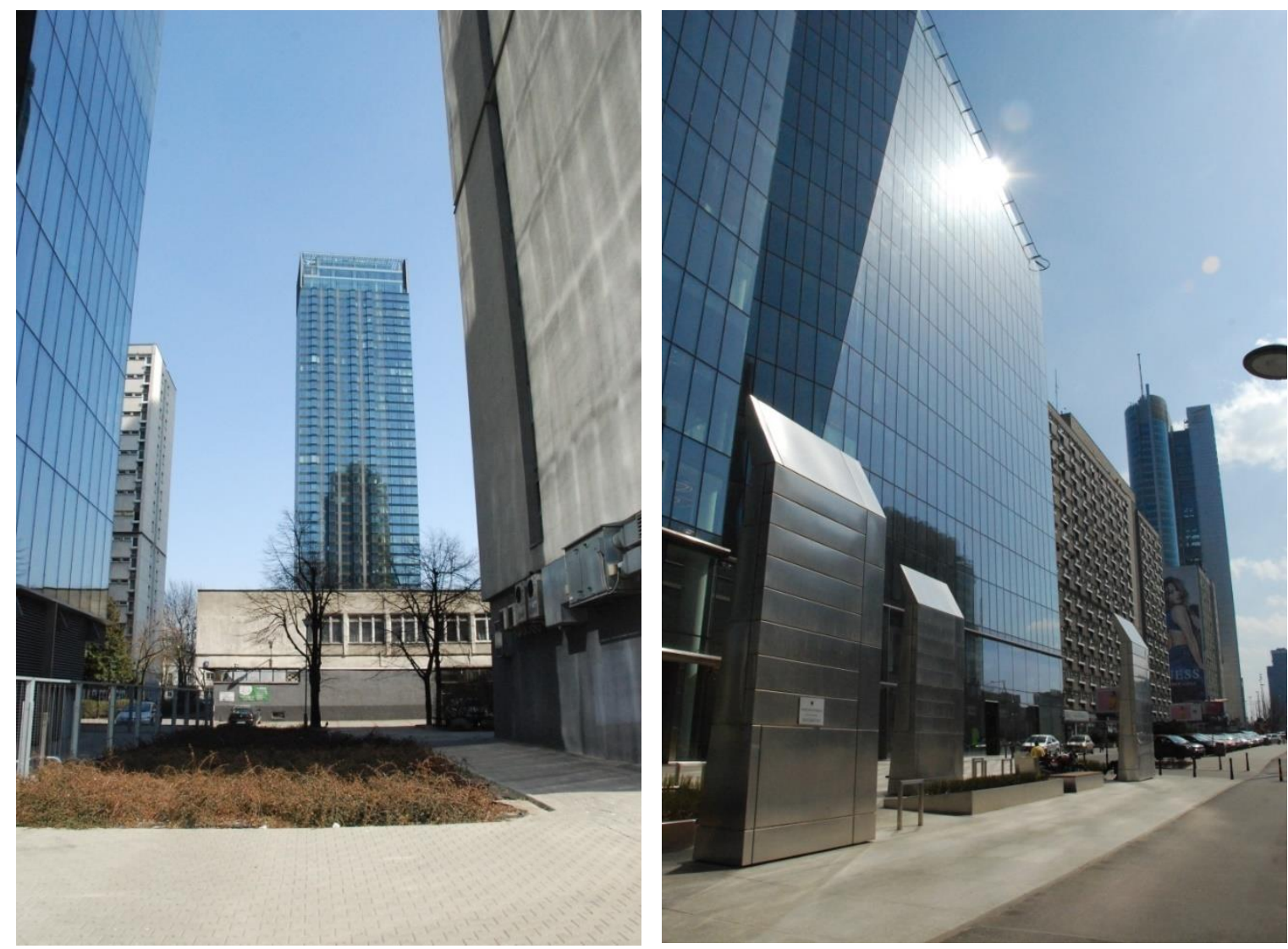

Fig. 5 and 6 Ul. Jana Pawła II (John Paul II Street) in a new postmodern spatial setting; 5 - Educational and cultural services in the form of two-story pavilions, enriching the space inside the quarters, were left between the new office skyscrapers; 6 the decor of the exterior of the street façades. It impresses with boldness of formal minimalism and of street devices for public transport - elegance, simplicity, smooth wall surfaces and no urban life (photo by Gruszecka K., 2018)

Ryc. 5 i 6 Ul. Jana Pawła II w nowej postmodernistycznej oprawie przestrzennej; 5 - Między nowymi wieżowcami biurowymi pozostawione usługi oświaty i kultury w formie dwukondygnacyjnych pawilonów wzbogacające przestrzeń wewnątrz kwartałów; 6 - imponująca śmiałością minimalizmu formalnego "szata" zewnętrzna fasad przyulicznych i na ich podobieństwo wymodelowanych urządzeń ulicznych obsługi środków transportu zbiorowego - elegancja, prostota, gładkie powierzchnie ścian i brak życia miejskiego (fot Gruszecka K., 2018) 
Questions arise whether these vast areas of office districts in Downtown Warsaw can be called new centres of Warsaw, if they remain empty during the day? Is the transformation of the downtown of the largest metropolis in Eastern Europe to consist in depopulating its centre? Is this the future vision for the downtown of the Polish capital city? If this process is to continue, the author of the present article, who undoubtedly belongs to the $X$ generation, will definitely change her substantive position. She chooses to join the ideology of the $Z$ youth, as she shares their position that the city should be filled with attractions for people, easily accessible by bicycles and scooters as well as on foot, with greenery-covered areas for strolling, resting and relaxation in an attractive spatial environment. The existing mono-functional designs give the impression that time has suddenly stopped. Given the above fact, it seems that modern urban planning in post-communist times continues for an unknown reason. Therefore, further in the article, the author presents the inspirations of the implemented designs worldwide (USA, Great Britain). They provide documented examples of a new approach to urban activities on various scales and for various communities.

\section{AMERICAN PATTERN FOR DEVELOPMENT OF URBAN STRUCTURE - TECHNOLOGICAL PARKS}

The famous American Silicon Valley and other similar workplaces in America may provide a model or inspiration. These facilities have been erected among very attractive landscapes with lots of greenery, among mountains, with natural and artificially established water reservoirs.

In US smaller cities, workplace districts that function as technological parks are created. Some of them feature not only office buildings, but also apartments in multi-storey buildings. Moreover, on small plots of land, bungalows or two-storey houses, usually for rent for the duration of corporate work, are built. This fact confirms the abovementioned thesis on frequent changes of the workplace by younger generations of employees, who strive at constant development of their work skills (Jaruzelski B., 2014). The design of The Massachusetts Institute of Technology in Cambridge, Massachusetts is an example of this approach. The area also includes a general reception building, a car park, recreational green areas. Therefore, the complex is characterized by a programme variety in addition to workplaces. It is equipped with additional functions necessary for an employee-friendly life in this particular place.

Implementation of technological parks with such a diverse structure in cities of varying sizes served multi-purpose goals in the USA at the end of the 20th century. Their function relied mainly on creating favourable conditions for small-size innovative companies to expand. Attempts to achieve such an effect resulted in the so-called "cross fertilization". The phenomenon consisted in situating technology parks within the territorial reach of universities, universities of technology or other scientific institutions in order to provoke mutual cooperation in the search for new technological solutions. At the same time, technological parks, as they were substantially located in between of universities and industrial production, became a tool of regional development. Technological parks led to an increase in the number of workplaces. In addition, introduction of technological parks provided a way to thin out huge industrial centres, as these areas created in the previous era of industrial production, tended to be overpopulated. In the era of transition from the industrial age to the knowledge society, i.e. to the next global level of civilization, these institutions contributed to the reduction in the population of cities. In Poland, a positive phenomenon of introducing such economic zones in medium-sized cities is observable. However, their internal structure calls for improvement. Nowadays unexciting, such economic zones could create wonderful living conditions, including for the operation of avid rationalizers.

If services and recreational areas were located within a short distance, merely next door, it would be easier for employees to fully engage in work knowing that all their needs will be met on the spot. In the Google headquarters in Silicon Valley, even a special room has been installed with a wall incorporating a fish tank and comfortable couches, so that employees can take a nap during work, e.g. for an hour or two. It might help refresh their minds and be more productive at work-related tasks. It is no wonder then that the abovementioned mono-functional units, built in Warsaw 15-20 years ago, 
are being rebuilt and efforts are made to modernize them, i.e. convert them into units with various functions. Such solutions will certainly be accepted.

In Silesia, Poland, a large industrial district is located on the outskirts of Gliwice. In many ways, the area is a very innovative in character. However, a few years back, huge halls were built for e.g. assembly line production of car bodies (with an area of approx. $1 \mathrm{~km} 2$ ), with office space on the first floor for the manager and two specialists in service and computer design, as well as with parking areas. Such solutions are much less friendly to qualified employees than the American ones described above. This fact evidently proves the necessity to change the design of such workplaces, in order to adapt them to the needs of qualified personnel ${ }^{3}$.

A comparison between the equipment of American technology parks and economic zones from Silesia clearly indicates the need to modify the design approach to this type of production districts, where modern solutions are also programmed.

\section{EUROPEAN PRINCIPLES FOR DESIGN OF TRANSFORMED AND URBANIZED METROPOLITAN AREAS}

According to the theory developed in the 1990s, mono-functional (modernist) zoning was considered an outdated way of designing new elements of the city. Whereas, the belief in durability of such structures was deemed mistaken. Purely single-functional assumptions were proved to be a nonpermanent investment. The countries of old Europe learned that new concepts in the field of urban planning should be directed towards creating innovative urban developments in a more flexible and sustainable way. The authors of this theory believed that proper functioning of a development system with various functions can be achieved when a given group of units is of certain specific sizes and, above all, reaches a critical mass (Jencks Ch., Kropf K., p. 229) ${ }^{4}$. On the one hand, this view applies to a specific size of the area devoted to a building development unit (approx. 40 ha, i.e. roughly 650 $x 650 \mathrm{~m})^{5}$. On the other hand, this approach is met by the principle of diversity in such building development units. In this case, the point is not only to ensure program diversity, but also to attract companies and individuals who, through their activities, breathe new life into the activities cultivated in a given area. Such variety will ensure prosperity of the area. Transformation of the London Docks at the end of the 20th century into a part of Downtown London may be seen as an exemplary implementation of the principle. Therefore, it was necessary to ensure supra-local attractiveness of the planned or reconstructed places (in the case of the city centre, e.g. on the city scale). Moreover, attention was paid to limiting the area of the planned development units so that they could be fully navigated on foot. The authors of this theory mentioned several main functions that should be incorporated in a theoretical development unit. These included: "access to everyday shopping facilities, access to primary health care, school, kindergartens and cultural and entertainment functions", together with greenery (Jencks, Kroph, ibidem, pp. 230-231)

It was also highlighted that, as a rule, diversity was to concern not only the division of a given building development unit into individual functions, but also the diversity of functions within quarters of building developments. The division of functions was suggested in the 1:1 proportions, i.e. the balance between the number of flats and job posts. The aim was to strive at a number of workplaces similar in number to the total of inhabitants able and willing to work. In order to design individual elements of the urban structure in this way (mix-used building development units), it is necessary to conduct thorough analyses of the current condition, population, structure of the population, composition of families, professional preferences, interests, preparation for the profession and suchlike. Studies related to changes in the fields listed above should also be of constant interest to the relevant administrative services of the country, region or city authorities. However, the most detailed scale, i.e. the

\footnotetext{
${ }^{3}$ According to the author's own heuristic experiences of the in situ analysis of economic zones in Poland.

${ }^{4}$ This new theory, developed in 1992, was based on the concepts by Leon Krier and other consultants, including Christopher Alexander, Sir Andrew Darbyshire, Rob Krier, Elizabeth Plater-Zyberk, John Thompson and Francis Tibbalds. [quoted in: Jencks, Kropf, p. 229

${ }^{5}$ According to Mycielski, an architect who lived and worked in the Netherlands for many years, this can be up to one square kilometer, i.e. $1 \mathrm{~km} \times 1 \mathrm{~km}$, a space that can be covered on foot on a daily basis.
} 
scale of objects should be designed in such a way that the objects may be adjustable in terms of their use (i.e. change their functions as needed) - without disturbing the structure of the whole ${ }^{6}$.

Starting from the 1:1 proportion mentioned above, half of the analysed area of a fixed size comprises the primary function, and the other half consists of the remaining associated functions (Jencks Ch., Kropf C. 1992 pp. 229 - 231). Therefore, if half of the planned housing is allocated to the housing development, then the other half should consist of workplaces, services, greenery and recreation of all kinds. If the planned development covers a larger area, the next unit is developed in a similar arrangement. Each of these units is enveloped by communication routes planned on the outer contour of the area. The point is that development units should be self-sufficient, and the people living there should be able to settle all life problems within the pedestrian access. On average, it was assumed that such units could serve 3,000 - 5,000 inhabitants, as well as other types of users (e.g. employees of the service and office sphere in the area).

Within this theory, the principle regarding ownership of land and buildings is extremely valuable and differs significantly from Polish design systems. British experience from 1990s shows that the area of the individual should be characterized by a diversified ownership structure: private ownership, distribution of stocks, rental for small business purposes, housing associations or municipal ownership. While conducting project activities in metropolitan areas in Poland, we (that is decision makers and participants in these processes) are not used to such a diversity in terms of ownership. It is a pity, since elsewhere, all activities are conducted with consideration for these diverse conditions. Early involvement in the process of participation, consultation, expressing opinions and needs on the part of users of the planned areas is the way to success. Many dilemmas must be resolved in an unconventional manner (for example Urban Development Corporations in England). It is obvious that insufficient financial resources are allocated to the purchase of land for new construction. Currently, it is a problem faced by the administration of Wola and Śródmieście districts in Warsaw. In order to persuade developers to build certain services or flats on private land in downtown London, it was decided that these would be premises for rent, the profits would be split, while in return, developers were offered very cheap land in other parts of the city, where they could also build.

A similar situation occurs when constructing a service and office district in new, undeveloped areas. When office buildings are the dominant function, they may occupy up to $50 \%$ of the area, while the remaining half should consist of residential buildings, services, green areas, recreational areas and water facilities. It is important that office buildings are accompanied by publicly available services on the ground floors. The construction of an office district without services leads to the creation of forlorn districts, with empty streets during the day, active only in the morning hours of commuting and in the afternoon hours of returning home from work.

In turn, park greenery areas are not only comprised of greenery. In order to attract residents and other urban users, attractors are needed in the form of additional functions that serve as attractors liked best by various age groups of the local community. Even in the nineteenth century, in the publicly accessible Ogród Saski (Saski Garden) in Warsaw, there was a pavilion of mineral water pumproom. The waters were brought here from health resorts in other regions of Poland. The building of the Summer Theatre, where interesting performances were held, also existed in the area. The theatre brought together the Warsaw elite, but also families with children.

In accordance with the latest trends, greenery and park areas should also be additionally equipped with solar panel fields or other devices for the benefit of the climate or energy saving. In the case of solar panels, they lead mainly to savings on fees for hot water. The mission of building-free greenery areas is to introduce as many tools as possible conducive to obtaining fresh, healthy air in the urban tissue, both thanks to the properties of greenery and savings due to the installation of pro-energy devices. The climate is also improved by introducing air purifying materials, e.g. as covering of pedestrian routes or building walls 7 .

\footnotetext{
${ }^{6}$ Currently in Poland, due to the restrictive approach of lawyers to statutory provisions, it is impossible to change the function of the building, it is necessary to change the local law for a specific area. This takes a minimum of about 1 year, usually much longer, to obtain legal permission for such an action.

${ }^{7} \mathrm{New}$ technologies for the structure of external wall layers that absorb pollutants from the air.
} 
Today, it is still believed that investing in such devices pays off relatively slowly. However, voices can already be heard that in the view of the gradual increase in energy bills in the near future, it will soon appear that it is better to invest in solar panels and have one's own energy sources.

The above principles are currently discussed in the scientific community, also among experts with extensive practical experience in spatial planning at many scientific conferences. However, these rules cannot be applied in design practice because of the lack of updated legal regulations. On the other hand, the professional field of lawyers, who have recently dominated the planning processes within local development plans, apply the provisions of law dating to the 1960s. These regulations tend to be interpreted literally, which often shatters the current concepts in line with contemporary trends.

\section{NEW CONCEPT FOR CREATING MIXED USE DEVELOPMENT ON A SUSTAINABLE SCALE}

In the history of European urban planning, professional fields of architects and urban planners from Great Britain have provided inspiration of new trends in spatial planning, as well as in promoting innovative directions in architecture and urban planning. As it happens, the British Isles saw faster civilization processes than those in other parts of Europe. Instead of docks, warehouse and industrial production sites by the Thames, a completely different job program has been introduced locally. This mainly consists of services, offices, financial corporations, such as Canary Worth. Moreover, housing and recreation facilities have been developed. Individual post-industrial areas were so large in size that their design required attention to changes, as well as to proper control and management of these transformations. This approach resulted in the development of new rules, not only for selected parts of central London, but also for modern concepts of smaller cities. Such arrangements started to be promoted in Great Britain. The point was to arrive at proper designs of suburban areas, nearby towns of agglomerations which emerged in large numbers after World War II near larger cities. In Poland, the process was carried out without plans or a concept in mind, often on the basis of building conditions or implementation of the investor's plans. In Britain, on the other hand, ways to best shape these organisms for the future were considered.

In Great Britain, a pioneer of modern urban planning, in 1992 the principles of city design were discussed and developed with the help of a group of high-class specialists. The team included: investors, professional builders, representatives of financial institutions, urban planners and environmentalists. The Prince of Wales provided inspiration for these activities in 1989. It is a characteristic feature of the way power is exercised Great Britain that rulers feel obliged to rationally support the processes of ensuring favourable living conditions for their subordinates. At the end of the 20th century, Prince Charles played a similar role, as he inspired substantive work on the proper organization of investment processes in housing estates for the poorer groups of urban population in Great Britain (municipal housing estates). It would be a positive social phenomenon if Polish communities could also enjoy favourable conditions in cities "for people" and if Poland became a pioneer in Eastern Europe in this field. This, however, is not happening yet.

The aim of these interdisciplinary activities in Great Britain was to "... study and promote multi-functional urban development with diversified ownership structure" (Jencks, ibid.). The theory of designing new parts of cities in a sustainable manner had been developed and consulted with a group of the best specialists in architecture and urban planning in the world. The theory included the following ideas and principles.

Most importantly, a new category of development should come into use - Multifunctional Structural Planned Urban Development. (Wielofunkcyjna Strukturalnie Planowana Zabudowa MiejskaWSPZM). Such buildings are recommended as... "a way of building a new, more civilized and sustainable urban environment". Taking into account the social changes that have been taking place in the 21st century, the authors of this concept feel obliged to recommend such development units, as they are considered to be more durable (Jencks, ibi-dem) 


\section{THE FACE OF FUNCTIONAL DIVERSITY}

A clear concept of functional diversity in the case of urban development units, quarters of building developments and individual objects was put forward. The principle of multifunctionality was recognized as the guarantee for survival of building complexes. This applies to both the concentration of trade or other services, as well as areas dominated by residential functions. This assumption is supposed to limit commuting to places of residence, work and recreation. Provided that the area requirement for the unit under development is about 40-100 ha, such a unit, rimmed by road communication routes, may provide a model for a multi-functional city fragment, which is, at least partially, selfsufficient. Such an area will be far from serving as a "bedroom" located many kilometres of roads away from work, school, kindergarten or a health centre. Nor will it be a service centre devoid of clientele that inhabits the place and is not always willing, and will eventually become less and less willing, to come here for shopping. This was the case in London in the spring of 2018, when more than 1,800 stores were closed in the centre, owing to the shortage of customers in the mono-functional, service-only parts of downtown.

\section{CONCLUSION}

At the beginning of the process of creating a downtown centre area or a building complex (e.g. a commercial street or a concentration of services), an intuitive process of emergence of new services can be observed calmly and with delight. New services are introduced through attraction. However, when this process enters the state of constant development, it is necessary to control it through proper management. Excessive one-sidedness always leads to the decline in the popularity of the complex. The variety of functions according to the above-mentioned proportions must be taken care of, both in order to protect the interests of private owners of premises and investors, and in the name of the public interest. This must be done so that the concentration of services survives and successfully fulfils its functions for the local communities.

What should control of these processes entail? Firstly, such controls should be performed practically constantly, i.e. once every 2 years rather than once every 10 years. They should comprise comprehensive analyses of various elements of the existing state, as well as observation of changes and determining the directions of these changes. Each time, once the analytical material is obtained, a group of specialists should assess these conditions and the current development trends, as well as make appropriate maintenance decisions. For such control to be successful, proper management by an organization or a company with appropriate authorizations to act is required. A type of such an organisation led in Great Britain to a complete transformation of London's downtown area in over 20 years. In is advisable to follow the British example and to strive at positive transformations to be made in Poland. 


\section{WSPÓŁCZESNE ZASADY PROJEKTOWANIA URBANISTYCZNEGO METROPOLII. SKALA PLANOWANYCH JEDNOSTEK I RÓŻNORODNOŚĆ}

\section{WSTĘP}

Celem tego artykułu jest wyjaśnienie dlaczego miejsca pracy dla wielu osób tak daleko są położone. Zadać należy pytanie: czy rzeczywiście tak musi być? Rozwiązania urbanistyczne innych miast Europy Zachodniej posłużą odpowiedzią na to pytanie. Oprócz lokalizacji w mieście dzielnic usługowych, biurowych czy przemysłowych, czyli kształtowania funkcjonalno-przestrzennego struktur miejskich przedstawione będą te elementy sieci miejskiej, których sposób projektowania oraz rezultat tych procesów muszą być dokonane obecnie w całkiem nowy sposób, żeby miasto funkcjonowało sprawnie, a ludzie cieszyli się z przyjaznych im rozwiązań.

Metodą dochodzenia do wniosków określających konieczność zmiany projektowania miasta i jego przekształceń, będzie porównanie stanu zastanego miasta (najczęściej Warszawy), zarówno od strony codziennego funkcjonowania, jak i oceny wszelkich zalet i wad tego systemu, z innymi lepszymi schematami projektowania, w krajach starej Europy (zwłaszcza z Londynem - przodującą metropolią świata pod względem stosowanych tam zasad urbanistyki).

We wnioskach czerpana będzie wiedza zarówno z przykładów pozytywnych rozwiązań w skali światowej, jak również z ustalonych już i utrwalonych w praktyce teorii urbanistycznych, porządkujących współczesne zasady projektowania, obowiązujące na Zachodzie począwszy od lat 70-tych, w Polsce ciągle nie doceniane.

\section{URBANISTYKA MODERNISTYCZNA NA TLE WSPÓŁCZESNYCH TRENDÓW}

Projektowanie urbanistyczne w erze modernizmu polegało na wyznaczeniu konkretnych terenów dla zabudowy mieszkaniowej, usługowej (centra hierarchiczne: miejskie, dzielnicowe i lokalne osiedlowe), przemysłowej, czy dla terenów rekreacyjno-sportowych. Powstawały zatem najczęściej duże skupiska zabudowy mieszkaniowej, gdzie wprawdzie istniały, chociaż niekompletne tzw. usługi podstawowe czyli niezbędne do egzystencji każdej rodziny: szkoły, przedszkola, żłobek, ośrodki zdrowia, czasem pojedyncze sklepy spożywcze. Jednak po większe zakupy trzeba było jeździć do centrum dzielnicy lub miasta. Podobnie miejsca pracy koncentrowano w osobnych dzielnicach. Na korzyść tych układów trzeba podkreślić znaczną ilość zieleni w zespołach mieszkaniowych - problem do którego dziś wracamy (Wojtowicz W., 2019)

Większe dzielnice przemysłowe zawierały jedynie zakłady produkcyjne i magazynowe, brak było dodatkowych funkcji wspomagających. Podobnie tereny rekreacyjne np. parki czy boiska sportowe były wypełnione zielenią i boiskami do gry bez żadnych dodatkowych atrakcji, czy usług, związanych z komfortowym spędzaniem w nich czasu.

Współcześnie wszystkie te sfery naszego życia: mieszkanie, praca i odpoczynek, są wspierane różnorodnością programu towarzyszącego. To nie tylko wsparcie funkcjonalne, ale wręcz wzbo-gacenie środowiska przestrzennego, w którym żyjemy, by nasza egzystencja była atrakcyjna i przyjaźnie zrównoważona.

\section{WZGLĘDNE POJĘCIE ATRAKCYJNOŚCI PRZESTRZENI MIEJSKIEJ}

O względnym pojęciu atrakcyjności przestrzeni miejskiej mówi stosowany już dość powszechnie podział społeczeństwa na pokolenie X, Y, Z. Młodzi reprezentanci pokolenia Z (w wieku przeciętnie od 19 do 26 lat), biorcy wszelkich najnowszych technologii, nie zawsze prozdrowotnych, i zmiennych pomysłów na karierę zawodową oraz spędzania czasu wolnego, mają całkowicie inne poglądy jak żyć interesująco, przyjemnie i z sukcesem. Jeżeli okazuje się, że w konkretnym miejscu pracy młody człowiek wyczerpał już możliwości pogłębiania swojego rozwoju, to zmienia miejsce pracy (Rykla Z., 
Kinala J., 2016) Pozytywnym aspektem pracy jest zatem rozwój osobisty jednostki. Natomiast pokolenie $Y$ jest na ogół trudne, ponieważ zbuntowane i protestujące przeciwko wszystkiemu, a pokolenie $X$ to już starsi powojenni ludzie, przepełnieni wiedzą, doświadczeniami, przesadnie dobrze się ubierający, pełni wartości i zasad, których młodsi nie rozumieją, ponieważ nie są dla nich istotne (Rykla Z., ibidem).

Wobec przyspieszenia zmian jakie już nastąpiły w drugiej połowie XX wieku i dalej się dokonują w szybkim tempie, projektowane środowisko przestrzenne musi zaspokajać potrzeby, ambicje i marzenia wszelkich grup społecznych uczestniczących w życiu metropolii, które, jak uzasadniono powyżej, są zdecydowanie zróżnicowane. Dyskutując często z młodzieżą akademicką i młodymi architektami o modelach miasta, które spełniałoby ich potrzeby słyszymy często, że miasto powinno być jak gra komputerowa: szalone, pełne niespodzianek, zaskakujących atrakcji, budzących zarówno podziw jak i zdumienie, prowokujących do nietypowych zachowań, kreowania rzeczywistości przy pomocy najnowszych wynalazków ( $w$ domyśle technologii czy nurtów aktywności). Różni się to od potrzeb starszych pokoleń, które wprawdzie będą zadowolone jeśli ich miasto dostarczy im wielu bodźców pozwalających na spełnianie potrzeb i rozrywki, ale w bardziej umiarkowany sposób.

Z rozważań tych wynika, że dla satysfakcji wszystkich grup wiekowych, nasze miasta potrzebuja różnorodnych przestrzeni (na otwartych terenach i przykrytych zadaszeniami), w różny sposób zagospodarowanych, spełniających każdorazowo potrzeby stylu bycia i spędzania czasu przez te grupy.

\section{CHARAKTERYSTYKA PIERWSZYCH REALIZACJI NOWYCH CENTRÓW W ŚRÓDMIEŚCIU WARSZAWY PO 1989 ROKU}

Na początku poddane analizie będą nowe realizacje, które gwałtownie wzrastały po 1989 r., opierając się na zasadzie synergii. W wielu miastach, a szczególnie wszędzie w Warszawie powstały nowe zespoły zabudowy na terenach poprzemysłowych, pokolejowych i poportowych. Wraz z przełomem politycznym 1989 roku nastąpiła likwidacja przemysłu wszelkiego rodzaju: zarówno na Służewcu Przemysłowym w Warszawie, na Woli, ale także na terenach pokolejowych w północnej części Śródmieścia. Ponadto zagospodarowywano także wolne od zabudowy tereny wzdłuż Al. Jerozolimskich - głównej trasy W-Z stolicy, gdzie powstała dwustronna obudowa usługami wielko-powierzchniowymi i biurami tej ulicy od granic Śródmieścia aż do granic miasta stołecznego Warszawy (ryc. 2)

Kolejny przykład wejścia w epokę poprzemysłową na początku lat 90-tych XX wieku to zamknięcie także portu nad Wisłą na Pradze Północ (Gruszecka K. Kordek M.). Charakterystyczne, że podobne procesy miały miejsce $\mathrm{w}$ innych stolicach Europy $\mathrm{np}$. w Londynie, gdzie już w latach osiemdziesiątych zlikwidowano zagospodarowanie przemysłowe w centrum obok tzw. Londyńskich Doków. Okazało się bowiem, że potrzeba miejsc do zatrzymania i przeładunku znacznie większych statków przewożących wydobywane kopaliny w innych krajach świata. Głębokość Tamizy nie pozwalała na przepływ takich dużych i ciężkich ładunków. Port przeniesiono bliżej ujścia rzeki do morza8 Dawne doki stanowią dziś dobrze funkcjonujące enklawy wielofunkcyjnych zespołów usługowo-mieszkaniowych, chociaż przemiany te nie były łatwe, wymagały wręcz zmiany zasad planowania i realizacji ${ }^{9}$.

Natomiast w Warszawie, stosunkowo szybko po 1989 roku powstały mono-funkcyjne zespoły wyłącznie biurowe jak wzdłuż ul Jana Pawła II, podobnie ciągi biur bez żadnych usług w parterach wzdłuż północnej pierzei Al. Jerozolimskich - na długości kilku kilometrów i podobnie wyłącznie zespoły wielkopowierzchniowych usług handlu po południowej stronie tejże ulicy. Zastosowano dokładnie zasady kształtowania z ery modernizmu wielkich zespołów o jednorodnych funkcjach i nawet podobnych układach przestrzennych obiektów.(ryc.1). Swoistym przykładem jest teren dawnego

\footnotetext{
${ }^{8}$ W rozprawie doktorskiej mgr inż. arch. Jolanty Cory pt.: Geneza struktury przestrzennej Londyńskiej Krainy Doków" autorka prezentuje dokładnie cały proces likwidacji zagospodarowania produkcyjno-magazynowego londyńskich doków z czasów wielkiego imperium Wysp Brytyjskich panujących w licznych koloniach świata i sprowadzających do tych portów kopaliny wydobyte w dalekich zamorskich krajach m.in. jak węgiel, rudę żelaza, wełnę, bawełnę, pszenicę itp. produkty; Biblioteka Wydziału Architektury Politechniki Warszawskiej 2019.

${ }_{9}^{9}$ Struktury i zasady działania Urban Development Corporations będą opisane w drugiej części artykułu m.in. dotyczącej zarządzania i porównania tych metod w Polsce właśnie z Wielką Brytanią pod względem skuteczności działań.
} 
Służewca Przemysłowego, dziś nazywany Mordorem, całkowicie wypełniony obiektami biurowymi, które czasem są już burzone po 10 latach ich istnienia, by postawić tam jednak trochę zabudowy mieszkaniowej wielorodzinnej.

Z kolei na terenie Portu Praskiego, który jakby się wydawało powinien, przynajmniej w pewnej części być ogólnie dostępnym terenem usług i rozrywki dla mieszkańców i turystów, z widokiem na przeciwny brzeg Wisły i panoramę historyczną miasta. Jednak inwestor z uporem od kilku lat próbuje wprowadzić apartamentowe budynki kilku kondygnacyjne zajmujące pirsy dawnego portu. Pytanie, czy jednak ten wyjątkowy krajobrazowo fragment miasta nie powinien być udostępniony mieszkańcom i użytkownikom tych terenów, tym bardziej, że przylega do chronionej strefy z nadwiślańską zielenią Natura 2000 (Guranowska-Gruszecka K., Kordek M, ) (ryc. 4).

Dziś średnio po 15-25 latach funkcjonowania tych mono-funkcyjnych zespołów zabudowy, czasami robiących wrażenie księżycowego krajobrazu bez ludzi, bez ruchu i bez życia, chociaż jest to centrum miasta, a architektura budynków imponująca, współczesna, minimalistyczna i bardzo elegancka. Mieszkańcy i użytkownicy tych terenów, a w szczególności architekci i urbaniści zauważają, że stosowanie takiej mono-funkcyjności na dużych terenach w centrum metropolii lub na jego obrzeżach było jednak pomyłką. Pojawiają się bulwersujące środowisko urbanistów przypadki wyburzania 4-kondygnacjowej zabudowy mieszkaniowej, realizowanej 10 lat temu wg projektu, który uzyskał I nagrodę w konkursie architektonicznym, by zbudować wyższe budynki mieszkaniowe, czyli uzyskać więcej metrów kwadratowych powierzchni do sprzedaży ${ }^{10}$.

Dokonano już odkrycia, że zespoły zabudowy biurowej wymagają także zaopatrzenia w przyległe do nich lub będące na ich obszarze, chociaż niewielkie tereny rekreacyjne $z$ ławkami $z$ zagospodarowaniem atrakcyjną zielenią, i także z elementami wodnymi (drobne zbiorniki, fontanny itp). Uwarunkowania klimatyczne naszych czasów oraz zasady wykonywania prac, nawet w korporacjach wymagają krótkich przerw na spożycie posiłków lub odpoczynek w dobrych warunkach estetycznych i zdrowotnie akceptowalnych. Korzystne jest także zaopatrzenie tych zespołów w ciągi handlowe na otwartym powietrzu lub przykryte. Dziś już wiadomo, że takie uzupełnienie tych zespołów biurowych jest konieczne ze względu na potrzeby stworzenia lepszych warunków wykonywania zadań biurowych.

Należy zadać pytania, czy rzeczywiście te rozległe tereny dzielnic biurowych w śródmieściu metropolii warszawskiej można nazwać nowymi centrami Warszawy, skoro w ciągu dnia są puste? Czy przekształcanie śródmieścia największej metropolii Europy Wschodniej ma polegać na wyludnieniu jej środka? Czy taka jest przyszła wizja centrum stołecznej metropolii Polski? Jeżeli tak ma dalej być, to autorka niniejszego artykułu niewątpliwie należąca do pokolenia powojennego $X$ zdecydowanie zmienia swoje stanowisko merytoryczne i przyłącza się do ideologii młodzieży z pokolenia Z, uważając że miasto powinno być wypełnione atrakcjami dla ludzi, łatwo dostępnymi zarówno przy pomocy rowerów i hulajnog jak i pieszo, ale wtedy w zieleni z miejscami spacerów, odpoczynku, relaksu w atrakcyjnym środowisku przestrzennym. Biorąc pod uwagę, że dotychczasowe mono-funkcyjne realizacje robią wrażenie, jakby czas się nagle zatrzymał, wygląda, że modernistyczna urbanistyka w czasach pokomunistycznych z niewiadomego powodu dalej trwa. Dlatego poniżej w artykule autorka przedstawia inspiracje dokonanych realizacji w skali światowej (USA, Wielka Brytania) stanowiących udokumentowane przykłady nowego spojrzenia na działania urbanistyczne w różnych skalach i dla różnych społeczności.

\section{AMERYKAŃSKI WZORZEC KREOWANIA ROZWOJU STRUKTURY MIEJSKIEJ - PARKI TECHNOLOGICZNE}

Pewnego rodzaju wzorem czy inspiracją może być amerykańska słynna Dolina Krzemowa i inne podobne zespoły miejsc pracy z tamtego kontynentu. Okazuje się, że są one wznoszone na bardzo atrakcyjnych krajobrazowo terenach z dużą ilością zieleni, wśród gór, z naturalnymi i sztucznie zakładanymi zbiornikami wody.

\footnotetext{
${ }^{10}$ Incydentalne przypadki występujące współcześnie na Służewcu Przemysłowym
} 
W mniejszych miastach w Stanach Zjednoczonych powstają dzielnice miejsc pracy, będących parkami technologicznymi. Niektóre, zawierają nie tylko obiekty biurowe, ale także mieszkania w budynkach kilkukondygnacyjnych oraz także na niewielkich działkach w postaci domków jedno- czy dwukondygnacyjnych zwykle do wynajęcia na czas pracy w korporacji. Potwierdza to wzmiankowaną wcześniej tezę o częstych zmianach miejsca pracy przez młodsze pokolenia pracowników, dążące do stałego rozwoju swoich umiejętności (Jaruzelski B., 2014). Przykładem jest plan Massachusetts Institute of Technology - Cambridge, Massachusetts. Teren zawiera także ogólny budynek recepcyjny, parking, tereny zieleni rekreacyjnej. Jest to zatem zespół charakteryzujący się różnorodnością programową, oprócz miejsc pracy wyposażony w inne funkcje niezbędne do przyjaznego pracownikom życia w tym konkretnie miejscu.

Zakładanie parków technologicznych o takiej właśnie różnorodnej strukturze w miastach o zróżnicowanej wielkości miało pod koniec XX wieku w USA wielozadaniowe motywacje. Głównie chodziło o stworzenie dogodnych warunków do promowania małych innowacyjnych firm. Próbowano tego dokonać powodując powstanie efektu tzw. "krzyżowego zapładniania". Polegało ono na lokalizacji parków technologicznych w zasięgu terytorialnym uniwersytetów, politechnik, czy innych placówek naukowych, w celu sprowokowania wzajemnej współpracy w poszukiwaniach nowych rozwiązań technologicznych. Jednocześnie instytucje te ulokowane merytorycznie między uczelniami, a produkcją przemysłową stawały się narzędziem regionalnego rozwoju, zwiększając liczbę miejsc pracy. Oprócz tego powoływanie do życia parków technologicznych stało się też sposobem na rozgęszczenie ogromnych ośrodków przemysłowych, przeludnionych, powstałych jeszcze w poprzedniej erze produkcji przemysłowej. W dobie przechodzenia od epoki przemysłowej do czasów społeczeństwa wiedzy, czyli już do następnego stopnia cywilizacji w skali globu, instytucje te przyczyniały się do zmniejszania zaludnienia miast. W Polsce pozytywnym zjawiskiem jest zakładanie takich właśnie stref ekonomicznych w miastach średniej wielkości, poprawy wymaga natomiast wewnętrzna struktura tych terenów. Są one dziś nieciekawe, a mogłyby stwarzać wspaniałe warunki do życia, w tym pracy zapalonych racjonalizatorów.

Mając w zasięgu nawet nie kilku minut, ale po prostu tuż obok, usługi i tereny rekreacyjne, pracownikom łatwiej w pełni zaangażować się w pracę, wiedząc, że wszystko zdążą załatwić na miejscu. W siedzibie googla w Krzemowej Dolinie nawet istnieje specjalne pomieszczenie ze ścianą z pływającymi w akwarium rybkami oraz ustawionymi wygodnymi leżankami, by móc się $\mathrm{w}$ ciągu pracy przedrzemać np. przez godzinę lub dwie, jeżeli pomoże to odświeżyć umysł i potem lepiej wypełniać swoje zadania. Nic zatem dziwnego, że w Warszawie wzniesione zespoły mono-funkcyjne 15-20 lat temu, opisane wcześniej w tym artykule, już są przebudowywane i z pewnością zaakceptowane będą dążenia, by je unowocześnić, czyli zamienić na zespoły o różnorodnych funkcjach.

W Polsce na Śląsku w wielkiej dzielnicy przemysłowej zlokalizowanej na obrzeżu Gliwic, mającej zresztą w wielu przypadkach bardzo innowacyjny charakter, już kilka lat temu funkcjonowały potężne hale np. taśmowej produkcji karoserii samochodowych (o powierzchni ok. $1 \mathrm{~km}^{2}$ ), z pomieszczeniem biurowym na I piętrze dla szefa i dwóch specjalistów obsługi i projektowania komputerowego oraz tereny parkingów. Są to znacznie mniej przyjazne wykwalifikowanym pracownikom warunki zatrudnienia, niż opisywane przykłady z USA. Przypadek ten świadczy ewidentnie o konieczności zmiany w projektowaniu takich miejsc pracy, w dostosowaniu do potrzeb pracującej wykwalifikowanej kadry ${ }^{11}$. Porównanie wyposażenia amerykańskich parków technolo-gicznych i stref ekonomicznych z polskiego Śląska dobitnie wskazuje na konieczność zmiany podejścia projektowego do tego typu dzielnic produkcyjnych, gdzie także programuje się te działania.

\section{EUROPEJSKIE ZASADY PROJEKTOWANIA PRZEKSZTALCANYCH ORAZ URBANIZOWANYCH OBSZARÓW METROPOLITALNYCH}

Zgodnie z teorią, która powstała w latach 90-tych, mono-funkcyjne (modernistyczne) strefowanie uznano za przestarzały sposób projektowania nowych elementów miasta, za mylne przekonania o trwałości takich struktur. Czyste jednofunkcyjne założenia okazały się nietrwałą inwestycją. W starej

\footnotetext{
${ }^{11}$ z własnych doświadczeń heurystycznych autorki analizy in situ istniejących w Polsce stref ekonomicznych.
} 
Europie wyciągnięto wnioski, że należy ukierunkować nowe idee urbanistyczne na tworzenie nowej zabudowy miejskiej, bardziej elastycznie i w zrównoważony sposób. Autorzy tej teorii uważali, że dobre funkcjonowanie układu zabudowy o różnorodnych funkcjach można uzyskać, kiedy ten zespół obiektów ma pewne konkretne wielkości, a przede wszystkim osiąga masę krytyczną (Jencks Ch., Kropf K., s. 229) ${ }^{12}$. Z jednej strony dotyczy to określonej wielkości obszaru jednostki zabudowy (ok. 40 ha, czyli orientacyjnie $650 \times 650 \mathrm{~m})^{13}$. Z drugiej strony służy temu zasada różnorodności w takich właśnie jednostkach zabudowy. Chodzi o to, by nie tylko zapewnić różnorodność programową, ale także żeby przyciągnąć firmy i jednostki, które swoją aktywnością tchną życie w działalność tu uprawianą, co zapewni dobrobyt. Przykładem takich działań jest przekształcenie Londyńskich Doków pod koniec XX wieku w cześć śródmiejską Londynu. Należało zatem dbać o wybitną w skali ponadlokalnej (w przypadku śródmieścia np. w skali miasta) atrakcyjność planowanych lub przebudowywanych miejsc. Jednocześnie zwracano uwagę na takie ograniczanie powierzchni planowanych jednostek, by można było w niej poruszać się w pełni pieszo. Wśród funkcji wymienianych przez autorów tej teorii, które powinny się $w$ tej teoretycznej jednostce znaleźć wymieniano;..."dostęp do codziennych zakupów, do podstawowej opieki zdrowotnej, do szkoły, przedszkoli i funkcji kulturalnych i rozrywkowych" z udziałem zieleni (Jencks, Kroph, ibidem, s. 230-231)

Zwracano też uwagę, że różnorodność ma dotyczyć nie tylko podziału tej jednostki zabudowy na poszczególne funkcje, ale także różnorodności funkcji w kwartałach zabudowy, jako zasady. Sugerowano podział funkcji w proporcjach 1:1 to znaczy równowagę między liczbą mieszkań i miejsc pracy, w dążeniu do zbliżenia się do podobnej liczby miejsc pracy jak liczba mieszkańców, zdolnych i chętnych pracować. Żeby w ten sposób projektować poszczególne elementy struktury urbanistycznej (mix-used jednostki zabudowy) należy prowadzić intensywne analizy stanu istniejącego, zaludnienia, struktury ludności, składu rodzin, preferencji zawodowych, zainteresowań, przygotowania do zawodu itp. Badania dokonujących się zmian w tym zakresie też powinny być przedmiotem stałego zainteresowania stosownych służb administracyjnych kraju, regionu czy samorządów miasta. Natomiast najbardziej szczegółowa skala, czyli obiekty powinny być tak projektowane, by możliwe było elastyczne traktowanie ich wykorzystania (czyli w miarę potrzeb zmiana funkcji) - bez naruszania struktury całości ${ }^{14}$

Wychodząc od powyższej zasady 1:1, połowa rozpatrywanego obszaru o ustalonej powierzchni mieści funkcję podstawową, a na drugą połowę składają się pozostałe funkcje towarzyszące (Jencks Ch., Kropf C. 1992 ss 229 - 231). Jeżeli zatem planowana jednostka mieszkaniowa może mieć połowę zabudowy mieszkaniowej, to na drugą połowę powinny się składać miejsca pracy, usługi, zieleń i rekreacja wszelkiego rodzaju. Jeżeli projektowane zagospodarowanie obejmuje większy teren, kolejna jednostka kompletowana jest podobnie. Każda z tych jednostek wydzielona jest komunikacją planowaną po zewnętrznym obrysie obszaru. Chodzi o to, żeby jednostki te były samowystarczalne, a ludzie tam mieszkający wszelkie problemy życiowe mogli załatwiać w granicach dojścia pieszego. Średnio przyjmowano, że mogą to być jednostki obsługujące 3 - 5 tysięcy mieszkańców i innych użytkowników (np. pracowników sfery usługowo-biurowej obszaru).

Niezwykle cenną i różniącą się bardzo od polskich systemów projektowania, jest zasada tej teorii dotycząca stanu własności terenów i budynków. Z doświadczeń brytyjskich z lat 90-tych XX wieku wynika, że obszar jednostki powinna charakteryzować zróżnicowana struktura własności: prywatna, podział akcji, wynajem dla małych firm, spółdzielnie mieszkaniowe, czy własności komunalne. W działaniach projektowych w Polsce na obszarach metropolitalnych nie jesteśmy przyzwyczajeni (decydenci i uczestnicy tych procesów) do takiej różnorodności własności, a szkoda, ponieważ gdzie indziej dokonuje się wszelkich działań, by te zróżnicowane warunki zaakceptować. Drogą prowa-

\footnotetext{
12 Ta nowa w 1992 roku teoria powstała na podstawie koncepcji Leona Kriera oraz innych konsultantów, , w tym: Christophera Aleksandra, sir Andrew Darbyshire'a, Roba Kriera, , Elizabeth Plater=Zyberk , Johna Thompsona i Francisa Tibbaldsa. [cyt.: Jencks,Kropf, s. 229]

${ }^{13} \mathrm{Wg}$ architekta Mycielskiego, który przez wiele lat mieszkał i pracował w Holandii może to być wielkość do jednego kilometra kwadratowego czyli $1 \mathrm{~km} \times 1 \mathrm{~km}$ przestrzeń możliwa do codziennego pokonywania pieszo.

${ }^{14} \mathrm{~W}$ Polsce obecnie wobec restrykcyjnego podejścia prawników do przepisów ustawowych, niemożliwa jest zmiana funkcji budynku, konieczną czynnością jest zmiana prawa miejscowego dla konkretnego terenu, co trwa minimum około 1 roku, najczęściej wielokrotnie dłużej, żeby uzyskać przyzwolenie prawne na takie działanie.
} 
dzącą do sukcesu jest jak najwcześniej mocne zaangażowanie użytkowników z planowanych terenów w proces partycypacji, konsultacji, wyrażania własnych opinii i prezentacji zapotrzebowań. Wiele dylematów musi być załatwiane niekonwencjonalnie (przykład Urban Development Corporations w Anglii). Oczywistym jest sytuacja niedostatecznych środków finansowych na wykup części gruntów pod nowe budownictwo. Obecnie jest to problem administracji Woli i Śródmieścia w Warszawie. Żeby skłonić developerów do budowy w śródmieściu Londynu niektórych usług czy mieszkań na terenach prywatnych zdecydowano, że będą to lokale na wynajem, zyski z tego będą podzielone, a w zamian developerzy dostali bardzo tanie tereny w innych częściach miasta, gdzie również mogli budować.

Podobna sytuacja zachodzi, kiedy konstruujemy na nowych niezagospodarowanych jeszcze terenach dzielnicę usługowo-biurową. Gdy dominującą funkcją są obiekty biurowe, mogą one zająć 50 $\%$ obszaru, natomiast na pozostałej połowie powinna znaleźć się zabudowa mieszkaniowa, usługi, tereny zieleni, rekreacyjne, także urządzenia wodne. Ważne jest, by obiektom biurowym towarzyszyły w parterach ogólnie dostępne usługi. Budowa dzielnicy biur bez usług prowadzi do powstawania dzielnic wymarłych o pustych ulicach w ciągu dnia, ożywiających się jedynie w godzinach porannych dojazdu do pracy i późno popołudniowych powrotów z pracy do domu.

$Z$ kolei tereny zieleni parkowej to nie tylko sama zieleń. Żeby przyciągnąć mieszkańców i innych użytkowników miejskich potrzeba atraktorów w postaci dodatkowych funkcji, atrakcji tego miejsca lubianego najlepiej przez różne grupy wiekowe lokalnej społeczności. Nawet w XIX wieku w publicznie dostępnym Ogrodzie Saskim w Warszawie, istniał pawilon pijalni wód mineralnych, sprowadzanych tu z uzdrowisk z innych regionów Polski oraz budynek Teatru Letniego, gdzie odbywały się interesujące przedstawienia skupiające elity warszawskie, ale także rodziny z dziećmi.

Zgodnie z najnowszymi trendami tereny zieleni, parkowej powinny być także dodatkowo wyposażone w pola solarów słonecznych lub inne urządzenia działające na korzyść klimatu lub oszczędności energetycznych. W przypadku solarów jest to oszczędność głównie na opłatach za ciepłą wodę. Misją terenów zieleni, wolnych od zabudowy jest wprowadzenie jak najwięcej narzędzi sprzyjających uzyskaniu świeżego, zdrowego powietrza w tkance miejskiej, zarówno dzięki właściwościom zieleni, jak i oszczędnościom z powodu zainstalowania urządzeń proenergetycznych. Poprawa klimatu następuje również poprzez wprowadzanie materiałów oczyszczających powietrze np. jako pokrycie ciągów pieszych lub ścian budynków 15. Dziś jeszcze się uważa, że inwestycja w takie urządzenia stosunkowo powoli się spłaca. Pojawiają się jednak już głosy, że wobec zwiększania się stopniowego, a w najbliższym czasie większych opłat za energię, okaże się w najbliższych latach, że lepiej opłaca się zainwestować w solary i dysponować własnymi źródłami energii.

Powyższe zasady omawiane obecnie w środowiskach naukowych, wśród ekspertów także o dużym doświadczeniu praktycznym w planowaniu przestrzennym na wielu konferencjach naukowych, nie są stosowane w praktyce projektowej, ponieważ brak jest zaktualizowanych przepisów prawnych. Natomiast środowisko zawodowe prawników, którzy w ostatnich kilkunastu latach zdominowali procesy planistyczne prawa miejscowego (mpzp), posługują się prawem z lat 60-tych ubiegłego wieku, próbując je literalnie interpretować, co często niszczy wprowadzane przez urbanistów do planów, aktualne współczesne idee.

\section{NOWE UJĘCIE ZRÓWNOWAŻONEGO ROZWOJU STRUKTUR MIEJSKICH (NEW CONCEPT FOR CREATING MIXED -USE DEVELOPMENT ON A SUSTAINABLE SCALE)}

W historii europejskiej urbanistyki, środowiska zawodowe architektów i urbanistów z Wielkiej Brytanii są w ostatnich stuleciach inspiratorami nowych trendów w planowaniu przestrzennym, także w promowaniu nowych kierunków w architekturze i urbanistyce. Tak się składa, że na wyspach brytyjskich procesy cywilizacyjne przebiegały szybciej niż w innych częściach Europy. Zamiast doków, terenów magazynowych i przemysłowych produkcyjnych nad Tamizą wprowadzono miejscowo całkowicie inny program miejsc pracy, głównie usług, biur, korporacji finansowych, jak np. na Canary Worth, ale

\footnotetext{
${ }^{15}$ nowe technologie struktury zewnętrznych warstw ścian, pochłaniające zanieczyszczenia z powietrza.
} 
także mieszkaniowy i rekreacyjny. Poszczególne tereny poprzemysłowe były tak duże, że ich projektowanie wymagało zastanowienia się nad zmianami, właściwej kontroli, zarządzania tymi przekształceniami. Przy okazji powodowało to opracowanie nowych zasad, nie tylko dla wybranych fragmentów centrum Londynu, ale także dla nowych koncepcji mniejszych miast, które zaczęto w Wielkiej Brytanii promować. Chodziło o właściwe zaprojektowanie terenów podmiejskich, miasteczek aglomeracji powstających licznie po II wojnie na terenach przy większych miastach. W Polsce odbywało się to bez planów i bez koncepcji, często na zasadzie warunków zabudowy lub realizacji planów inwestora. W Brytanii zastanawiano się jak dla przyszłości tych organizmów będzie najlepiej je ukształtować.

W Wielkiej Brytanii będącej pionierem nowoczesnej urbanistyki w 1992 r. przedyskutowano i opracowano zasady projektowania miast w gronie grupy specjalistów wysokiej klasy, w skład której wchodzili: inwestorzy, profesjonaliści budowniczowie, reprezentanci instytucji finansowych, architekci urbaniści, także ekolodzy. Inspiratorem tych działań w 1989 roku był JW Książę Walii. Dla sposobu sprawowania władzy w Wielkiej Brytanii jest charakterystyczne, że rządzący poczuwają się do misji racjonalnego wspierania procesów zapewniania dogodnych warunków egzystencji swoich podwładnych. Podobną rolę odegrał książę Karol jeszcze pod koniec XX wieku, inspirując prace merytoryczne nad właściwym zorganizowaniem procesów inwestycyjnych osiedli dla uboższych grup ludności miejskiej w Wielkiej Brytanii (osiedla zabudowy komunalnej). Pozytywnym zjawiskiem społecznym byłoby, gdyby i nasze polskie społeczności mogły cieszyć się dogodnymi warunkami w miastach "dla ludzi" i gdybyśmy stali się pionierami w Europie Wschodniej w tej dziedzinie. Na razie to nie następuje.

Celem tych interdyscyplinarnych działań w Wielkiej Brytanii było..."badanie i promowanie wielofunkcyjnej zabudowy miejskiej o zróżnicowanej strukturze własności" (Jencks, ibidem). Teoria dotycząca projektowania nowych fragmentów miast w sposób zrównoważony została opracowana i skonsultowana z gronem najlepszych specjalistów od architektury i urbanistyki w skali światowej, zawierając następujące idee i zasady.

Przede wszystkim powinna wejść w użycie nowa kategoria zabudowy - Wielofunkcyjna Strukturalnie Planowana Zabudowa Miejska. (WSPZM). Zabudowa taka jest rekomendowana jako..."sposób budowania nowego bardziej cywilizowanego i trwałego środowiska miejskiego". Biorąc pod uwagę zachodzące w XXI wieku zmiany także społeczne, autorzy tej koncepcji poczuwają się do obowiązku zarekomendowania takich właśnie zespołów, które oceniają jako bardziej trwałe (Jencks, ibidem)

\section{OBLICZE RÓŻNORODNOŚCI FUNKCJONALNEJ}

Postawiono jasną koncepcję różnorodności funkcjonalnej jednostek urbanistycznych zabudowy, kwartałów i poszczególnych obiektów. Zasadę wielofunkcyjności uznano jako gwaranta przetrwania zespołu zabudowy. Dotyczy to zarówno koncentracji handlu, czy innych usług, jak i obszarów o dominacji funkcji mieszkaniowych. Założenie to ma służyć ograniczeniu dojazdów do miejsc zamieszkania, pracy i rekreacji. Przy spełnieniu dla opracowywanej jednostki wymogu powierzchni na poziomie około 40-100 ha, jednostka taka, wydzielona komunikacją drogową, może być wzorcem wielofunkcyjnego fragmentu miasta, przynajmniej częściowo samo-wystarczalnego. Nie będzie "sypialnią" z której wielokilometrowe drogi prowadzą do pracy, do szkoły do przedszkola, czy do przychodni lekarskiej, nie będzie też centrum usługowym bez klienteli, która mieszka daleko od tego miejsca i nie zawsze, a w końcu coraz rzadziej ma ochotę aż tu przyjeżdżać po zakupy. Tak się stało w Londynie w 2018 r., kiedy na wiosnę owego roku zamknięto w centrum ponad 1800 sklepów, gdyż zabrakło klienteli w mono-funkcyjnych, usługowych jedynie, częściach śródmieścia.

\section{WNIOSKI}

O ile na początku procesu powstawania centrum w rejonie śródmieścia, czy zespołu (np. ulicy handlowej, czy koncentracji usług) spokojnie i z zachwytem można obserwować intuicyjne odbywające się drogą przyciągania powstawanie nowej koncentracji usług, kiedy proces ten wejdzie w stan sta- 
łego rozwoju, należy nad nim zapanować poprzez właściwe zarządzanie, gdyż przesada jednostronności zawsze prowadzi do upadku popularności zespołu. Różnorodność funkcji według omówionych wyżej proporcji musi być pilnowana zarówno w obronie interesów prywatnych właścicieli lokali i inwestorów jak i w imię interesu publicznego, by koncentracja usług przetrwała, pełniąc swe funkcje dla społeczności tych terenów.

Na czym polega kontrola tych procesów? Otóż powinny być wykonywane nie raz na 10 lat, ale praktycznie stale czyli np. raz na 2 lata kompleksowe analizy różnych elementów stanu istniejącego i również obserwacje zmian oraz określanie kierunków tych zmian. Każdorazowo po uzyskaniu materiału analitycznego należy w gronie specjalistów ocenić ten stan i występujące trendy rozwojowe oraz podjąć stosowne decyzje porządkujące. Żeby to uczynić musi istnieć właściwe zarządzanie przez organizację, czy firmę dysponującą stosownymi upoważnieniami do działania. Uprawnienia i działania takiej firmy, która w Wielkiej Brytanii doprowadziła w ponad 20 lat do całkowitego przekształcenia strefy śródmiejskiej Londynu, zostaną opisane w II części artykułu w następnym numerze kwartalnika.

\section{BIBLIOGRAPHY}

Aldous . Tony, The Urban Villages Group, Podsumowanie, Urban Village: A concept for Creating Mixed -Use Development on a Sustainable Scale, The Urban Village Group (London), 1992, s. 229 i nast.; in: Jencks Charles, Kropf Karl, Teorie i Manifesty Architektury Współczesnej, tłumaczenie: Daniela Szymczak, Warszawa 2013

Cory Jolanta, Geneza struktury przestrzennej Londyńskiej Krainy Doków - rozprawa doktorska pod kierunkiem Andrzeja Gawlikowskiego, 2019, biblioteka Wydziału Architektury Politechniki Warszawskiej.

Guranowska-Gruszecka K. Czynniki decydujące o sukcesie procesów rewitalizacyjnych na wybranych przykładach z Wielkiej Brytanii i ich porównanie z przykładami rewitalizacji w Warszawie - referat na Radzie Wydziału PW, 2016

Guranowska-Gruszecka K., Kordek M, Port Praski w Warszawie plany i rzeczywistość w: red.: Rembarz G. Mieszkać w porcie /Living in Harbour, wyd.: Polska Akademia Nauk - Komitet Przestrzennego Zagospodarowania Kraju, Gdańsk , 2019

Jaruzelski B., Why Silicon Valley's Success Is So Hard to Replicate; https://www.scientificamerican.com/article/why-silicon-valleys-success-is-so-hard-tp-replicate; (dostęp od; 14 marzec 2014)

red.: Rykla Zbigniew, Kinala Jarosław, Socjologia codzienności jako niebanalności, wyd.. Stowarzyszenie Naukowe Przestrzeń Społeczna i Środowisko, Rzeszów. 2016; ISBN 978-83-64879-01-2

Wojtowicz Wojciech, Zielona dzielnica SILO powstanie pod Jaworznem w: Urbnews.pl, portal o urbanistyce i gospodarce przestrzennej, 12.03.2019 


\section{AUTHOR'S NOTE}

An experienced urban planner with several hundred local development plans, development condition studies, directions for development, and other urban projects in her portfolio. Author of several books, including a monography "The Centre of Warsaw in the $20^{\text {th }}$ Century", editor and main author "Urban nodes". Expert of the contemporary principles of urbanism in world's scale. Architect with passion of introduction modern urban trends in Poland.

\section{O AUTORZE}

Doświadczony praktyk urbanista o dorobku kilkuset planów miejscowych i Studiów uwarunkowań i kierunków zagospodarowania oraz innych projektów urbanistycznych w całej Polsce. Autorka kilku książek naukowych m.in. obszerna „Śródmieście Warszawy w XX wieku”, redakcja i główna autorka "Węzły miasta". Znawca współczesnych zasad urbanistyki w skali światowej. Pasjonat wprowadzania, nowoczesnych trendów urbanistycznych w Polsce.

Contact | Kontakt: ka@post.pl 